\title{
Cretaceous ammonites from Fuerteventura, Canary Islands
}

\author{
OTTO RENZ*, DANIEL BERNOULLI† \& LUKAS HOTTINGER \\ * (Deceased) Museum of Natural History, Augustinergasse 2, CH-4051 Basel, Switzerland \\ $\dagger$ Geology Institute, Swiss Federal Institute of Technology, CH-8092 Zürich, Switzerland \\ $\ddagger$ Geological Institute of Basel University, Bernoullistrasse 32, CH-4056 Basel, Switzerland
}

(Received 18 November 1991; accepted 31 March 1992)

\begin{abstract}
Mesozoic deep-water sediments occurring on the island of Fuerteventura were deposited near the continent-ocean boundary adjacent to the African margin. During Tertiary times, they were uplifted and intruded by ultramafic, mafic and alkaline plutons and dykes and are now exposed as part of the 'Basal Complex' of the island. These sediments reflect more or less continuous hemipelagic and turbiditic deposition during most of Jurassic and Cretaceous times. Two ammonites, described in this paper, document a Valanginian to Hauterivian age for part of the Lower Cretaceous siliciclastic turbidites, and a latest Albian to early Cenomanian age for part of the Upper Cretaceous hemipelagic limestones.
\end{abstract}

\section{Introduction}

On the Canary Island of Fuerteventura, Mesozoic deep-water sediments occur (Fig. 1; Rothe, 1968; Robertson \& Stillman, $1979 a$; Robertson \& Bernoulli, 1982). These sediments were deposited near the continent-ocean boundary adjacent to the African margin; they were uplifted in Tertiary times and are now exposed as part of the 'Basal Complex' of the island (Fig. 2; Fuster et al. 1968; Stillman et al. 1975; Le Bas, Rex \& Stillman, 1986). The Basal Complex is a lithologically diverse assemblage. It is dominated by an extensive dyke-in-dyke swarm which was closely associated with the emplacement of ultramafic to mafic and alkaline plutons. Where visible, the host rocks to the dykes comprise Mesozoic and minor Lower Tertiary sediments and submarine volcanic rocks (Fuster et al. 1968; Robertson \& Stillman, $1979 a, b)$ which were affected by thermal metamorphism of low greenschist grade (chlorite-epidotequartz-albite) during the intrusion of the dykes and plutonic bodies.

The Mesozoic deep-water sediments document more or less continuous hemipelagic and turbiditic deposition on the deep Atlantic sea floor adjacent to the African margin. Fossils date the sediments as early Cretaceous and younger; however, in this part of the Atlantic oceanic sediments could be as old as late early or middle Jurassic. Indeed, if confirmed, the impressions of 'Posidonia' reported by Rothe (1968) from Barranco de Ajui (Unit B below) would extend the age of the sequence to the middle or early Jurassic. Earliest volcanic activity on Fuerteventura is documented by basaltic breccias, pillow lavas and volcaniclastic sandstones which overlie with apparent conformity and intercalate with Upper Cretaceous chalks and marls (Robertson \& Stillman, $1979 a$; Le Bas, Rex \& Stillman, 1986). Available radiometric age data suggest that the main phases of intrusion and build-up of the island took place over a period of over 40 m.y., from late Cretaceous to early Miocene (Le Bas, Rex \& Stillman, 1986). Previous to the extension connected with the emplacement of the main dyke complex in Oligocene time, the Mesozoic sediments were folded and partly overturned. Unroofing of some of the plutons in Oligocene times is suggested by the occurrence of reworked plutonic rocks in Oligocene bioclastic limestones (Le Bas, Rex \& Stillman, 1986). These limestones, which are part of the Basal Complex, document the proximity of areas of photic shallowwater carbonate deposition on a seamount or offshore shoal fringing an emergent volcanic edifice (Robertson \& Stillman, 1979a; Robertson \& Bernoulli, 1982). A thick pile of subhorizontal Neogene, post-early Miocene plateau basalts unconformably overlies the Basal Complex (Fuster et al. 1968).

The lithostratigraphy and sedimentology of the Mesozoic and early Tertiary sediments are relatively

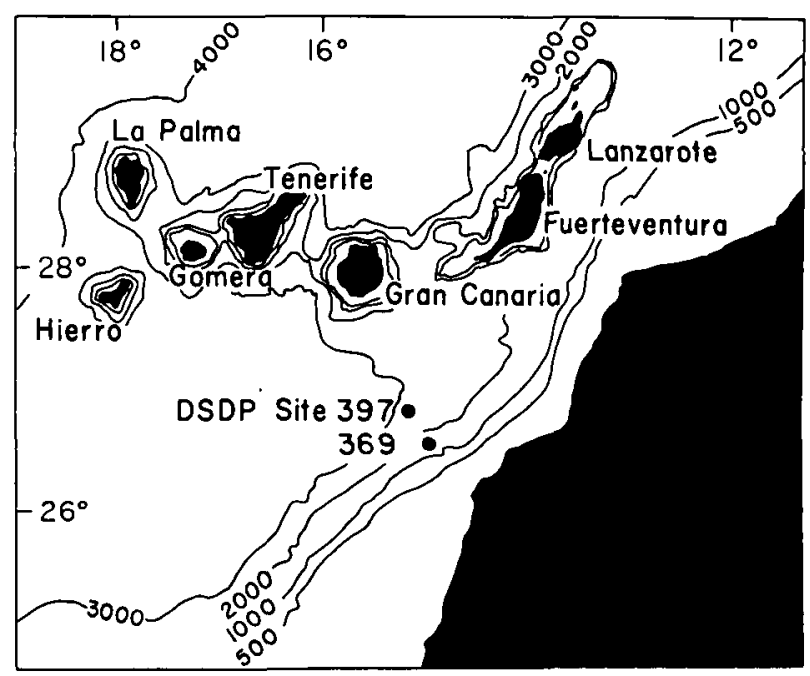

Figure 1. Location map of Fuerteventura, Canary Islands. 


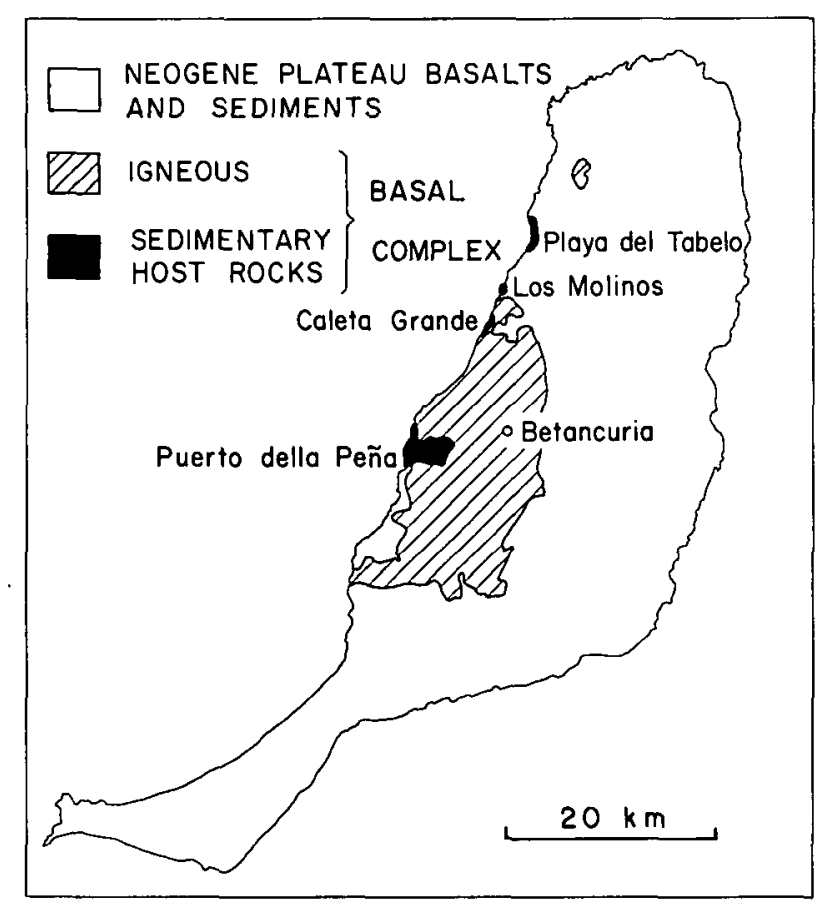

Figure 2. Simplified geological map of Fuerteventura.

well known (Robertson \& Stillman, 1979a; Robertson \& Bernoulli, 1982), but dating is poor. In this paper we document the occurrence of Cretaceous ammonites, mentioned in an earlier paper (Robertson \& Bernoulli, 1982), from the Mesozoic sequence of the Basal Complex. The sedimentary evolution of Fuerteventura has been discussed in detail by Robertson \& Bernoulli (1982), the early volcanic evolution by Le Bas, Rex \& Stillman (1986), and we refer to these papers for details and more extensive discussion.

\section{Stratigraphy of the Mesozoic sequence}

The Basal Complex is exposed in the western part of the island (Fig. 2). The Mesozoic stratigraphy has been established in the area between Puerto della Peña and Caleta della Peña Vieja along the barrancos near the western coast of the island (Fig. 3). Rothe (1968) stated that the Mesozoic sequence in this area was disposed in a major east-west-trending isoclinal overturned syncline. In contrast, Robertson \& Stillman (1979a), while confirming that the beds were predominantly overturned, established that the succession becomes uniformly younger towards the north, on the basis of sedimentary structures in redeposited sediments. Grunau et al. (1975) for their part did not recognize the overturned nature of the sequence between Puerto de la Peña and Caleta della Peña Vieja and thought the sequence to young to the south. This is clearly contradicted by sedimentological and fossil evidence (Robertson \& Bernoulli, 1982).

Robertson \& Stillman (1979a) and Robertson \& Bernoulli (1982) subdivided the Mesozoic sequence into seven lithological units (A to $G$ ). No base to the pre-volcanic sedimentary sequence is known, until now, from Fuerteventura. The oldest unit exposed, Basal Unit A, comprises epidotized black shales, grey siltstones, sandstones and marbles. It is overlain by a Calcarenite-Sandstone-Shale Unit (B) consisting of amalgamated bioclastic calcarenite turbidites and thin-bedded fine- to medium-grained yellow to pale grey turbiditic quartzarenites to quartzlutites.

Unit B passes gradually upwards into several hundred metres of dark grey to black silty shales interbedded with massive or weakly laminated thinbedded calcilutites (Unit $\mathrm{C}$ : Calcilutite-SiltstoneShale Unit). Units $A$ to $C$ are not dated palaeontologically; however, Rothe (1968) mentions 'impressions' of Posidonia from Unit B and infers a Liassic to late Jurassic age for Units A to $C$.

Up-section, the limestone interbeds gradually thin and give way to siliciclastic arenites and rudites interbedded with black shales and siltstones. Thick bedded quartzarenites often show complete Boumacycles whereas thinner-bedded sandstones show C-D-E or D-E divisions. The sandstones are arranged in thickening- and coarsening-upward sequences. Flute-casts show a prevailing sediment transport from the northeast or east. In the lower part of Unit D (Barranco della Peña), the finding of Neocomites sp., described below, indicates a Valanginian to Hauterivian age for part of the formation. A general Valanginian to Hauterivian age of Unit $D$ is supported by lithological correlation with the Lower Cretaceous sequence at Site 370/416 of the Deep Sea Drilling Project (Lancelot et al. 1980).

In Unit E (Homogeneous Siltstone Unit), the sandstones become finer and thinner up-section and give way to finely laminated quartzlutites, siltstones and black shales. A Barremian to Aptian age is tentatively assigned to this unit.

Units F and G (Marl-Calcarenite Unit and Thicker Bedded Marl and Chert Unit) consist of pelagic, partly redeposited limestones (Series 5 of Rothe, 1968). The lower part of the sequence comprises about $30 \mathrm{~m}$ of white to light grey foraminiferal/radiolarian chalks and marls with lesser calcarenites and a few calcirudites becoming more frequent up-section. The calcarenites are graded and contain in their lower parts clasts of siltstone, mudstone, black shale and chert from the underlying formations, phosphatic and shell fragments, fish teeth and intraclasts of pelagic chalk set in a pelagic limestone or chalk matrix (Robertson \& Bernoulli, 1982, fig. 8). Most of the chalk sequence is redeposited by slumping and mass flow processes. Up-section there is a relatively abrupt change to $30 \mathrm{~m}$ of still paler, more homogeneous marls and chalks with nodules of replacement chert and lesser redeposited beds.

In Units $\mathrm{F}$ and $\mathrm{G}$ two different faunal associations can be distinguished. From Caleta de la Peña Vieja, Rothe (1968) mentioned 'Globotruncana' of possibly 


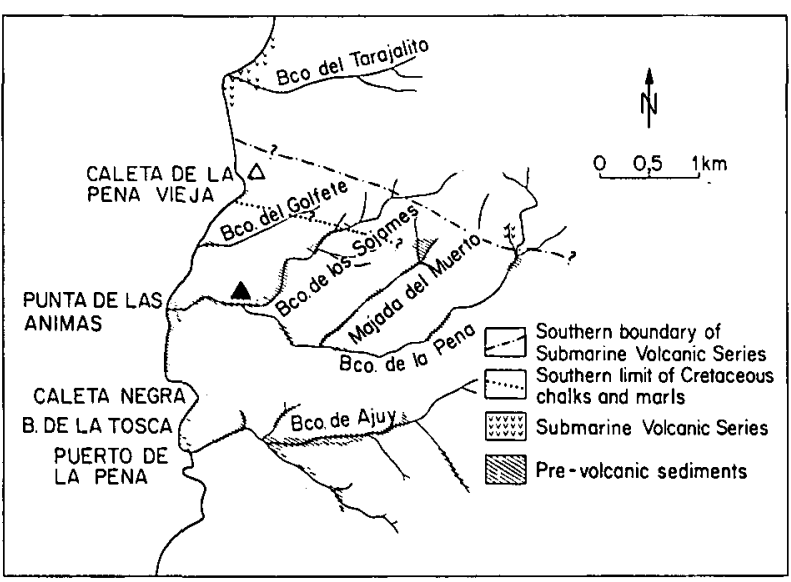

Figure 3. Map of the Mesozoic sedimentary sequences of the southern coastal exposures, Fuerteventura. After Robertson \& Stillman (1979a). Open triangle: fossil locality at Caleta della Peña Vieja; closed triangle: fossil locality at Barranco della Peña.

Albian age, without giving specific determinations. Lehmann (in Mitchell-Thomé, 1976) and Grunau et al. (1975) identified a number of planktonic foraminifera (Globigerina, Hedbergella, Globigerinelloides, Ticinella) and calcispherulids (Pithonella), also suggesting an Albian age. More specifically, a late Albian to early Cenomanian age can be assigned to the lower part of the sequence. This is based on an ammonite (Partschiceras cf. whiteavesi (Kossmat), described below) and on the following foraminiferal taxa: Schakoina gandolfii Reichel, Rotalipora sp., Hedbergella sp., and Gabonella sp. (Hottinger in Robertson $\&$ Bernoulli, 1982). The upper part of the sequence is clearly younger: a pre-Maastrichtian Coniacian to Campanian age is indicated by double-keeled globotruncanids, rare Heterohelicidae and benthonic foraminifera of the genera Stensiöina, Gavelinella, Polymorphina and Reussella (Hottinger in Robertson \& Bernoulli, 1982). The relations between the sediments containing these different associations are obscured by dyke intrusions and no Turonian fauna has been found thus far. A stratigraphical hiatus between the Upper Albian-Lower Cenomanian and the Coniacian-Campanian successions is suggested by analogy with a similar hiatus associated with slumping and soft sediment deformation observed at Site 369 of the Deep Sea Drilling Project (Lancelot et al. 1977).

The Upper Cretaceous sediments of Unit $G$ are overlain to the north by submarine volcanic rocks which locally alternate with chalks and marls, presumably still of late Cretaceous age (Le Bas, Rex \& Stillman, 1986). The relations between these volcanics and the Oligocene limestones at Caleta Grande (Robertson \& Bernoulli, 1982) are again obscured by dyke intrusions.

\section{Systematic palaeontology}

\section{Subclass AMMONOIDEA}

Material. The two ammonites found on Fuerteventura cannot be fully determined specifically because of their poor preservation. The stratigraphically older specimen comes from Unit D and was found at Barranco de la Peña (Fig. 3). It consists of a mould which has been preserved on the bottom surface of a turbidite bed. It belongs to the family Neocomitidae (genus Neocomites). The younger ammonite comes from Unit $F$ at Caleta de la Peña Vieja (Fig. 3) and occurs in a light-brown micritic limestone. It represents the juvenile stage of a representative of the genus Partschiceras which first appears in early Jurassic and extends into late Cretaceous time. Many species of the genus are distinguished by their longevity which makes an accurate age determination problematic.

The ammonites described are deposited in the Museum of Natural History, Basel, Switzerland under the numbers J 31312 to $\mathbf{J} 31318$. The Partschiceras(?) whiteavisi from southern India used for comparison in

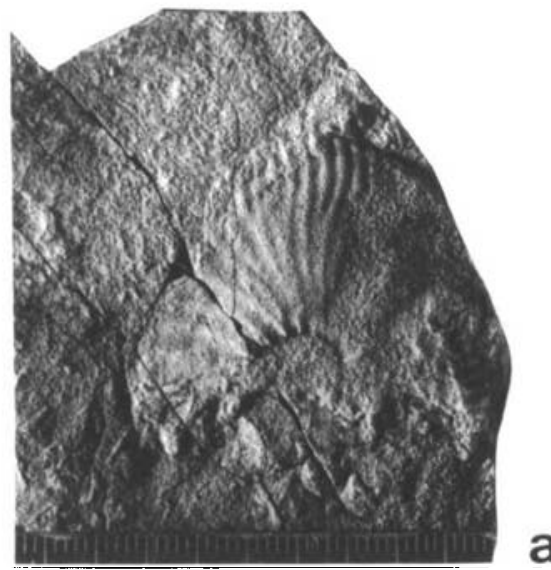

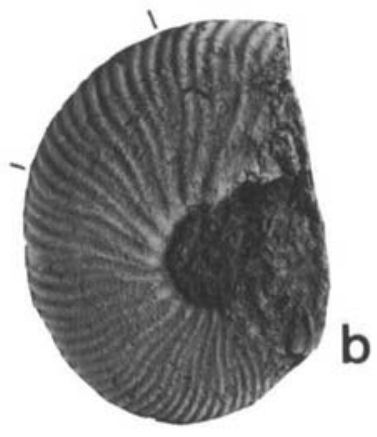

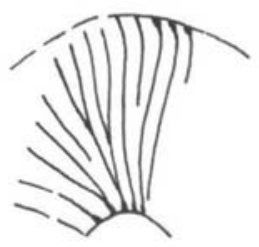

C

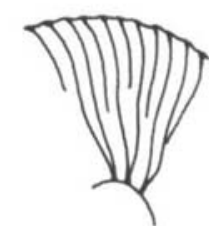

d

$10 \mathrm{~mm}$

Figure 4. (a) ?Neocomites from stratigraphical Unit D, Barranco de la Peña, Fuerteventura (Canary Islands). Museum of Natural History, Basel, no. J 31312. (b) Neocomites neocomiensis (d'Orbigny), Gemsmättli-Schicht (Valanginian), Mount Pilatus, Switzerland. Museum of Natural History, Basel, no. J 31313. (c, d) Rib patterns of (a) and (b) (c reversed for easier comparison). 

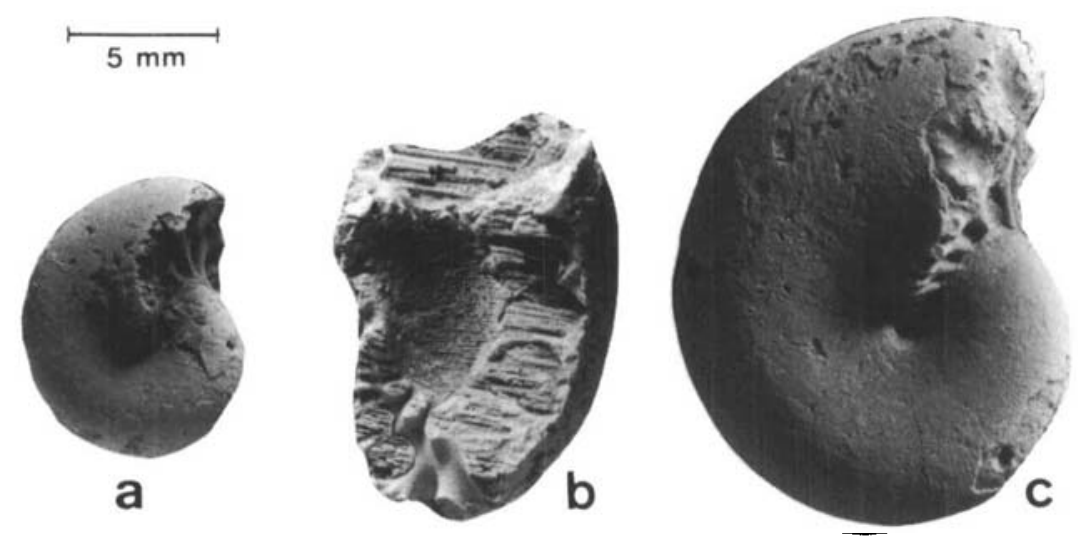

Figure 5. Partschiceras baborense (Coquand) from the Upper Aptian of San Telmo (Mallorca) showing a fine ribbing on the test. (a) The outer whorl has been removed (specimen illustrated in b). Museum of Natural History, Basel, no. J 31314. (b) Detached whorl fragment of specimen illustrated in (a) showing the fine ribs. (c) On this specimen, the test is mostly preserved but badly worn. The ribbing is faintly preserved on the right half. Museum of Natural History, Basel, no. J 31315.

Figure 6 has been described by Wiedmann (1963, p. 249 , fig. 58) and is deposited under the number Wi ' $U A M$ ' $/ 3$ in the Museum of Natural History in Geneva.

Family NEOCOMitidae Salfeld, 1921

Subfamily NEOCOMITINAE Salfeld, 1921

Genus Neocomites Uhlig, 1906

(Fig. $4 \mathrm{a}-\mathrm{d}$ )

Description. Seven rather fine, closely spaced, markedly flexuous prorsiradiate ribs, branching in small bunches from feeble umbilical tubercles are preserved. These ribs branch again towards the middle of the flank or higher up on the whorl, terminating in small, apparently slightly oblique bullae. The coiling seems to have been rather involute and the umbilical edge pronounced (Fig. $4 \mathrm{a}, \mathrm{c}$ ). The venter is not preserved.

Discussion. The aspect of the ribs suggests a comparison with some forms belonging to the genus Neocomites, as figured by Sayn (1901) from the Valanginian of southeastern France. The specimens figured on his plate 7, figures 10 and 11 (Neocomites neocomiensis (d'Orbigny)) have all of the features of the present specimen.

For a further comparison we have chosen a Neocomites neocomiensis from the Valanginian of the Helvetic sequence of the Swiss Alps. The whorl segment corresponding to the specimen from Fuerteventura is marked by two lines on Figure $4 \mathrm{~b}$. The identity of the morphological features of the two segments (according to Fig. 4c,d) can hardly be doubted.

Based on the occurrence of this ammonite which most probably belongs to the genus Neocomites, a Valanginian to Hauterivian age is suggested for the turbidites of Unit D.

Family PHYLlOCERATIDAE Zittel, 1884

Subfamily PHYLloceratinae Zittel, 1884

Genus Partschiceras Fucini, 1923
Discussion. Before discussing the specimen from Unit $\mathrm{F}$, a few additional remarks concerning the species Partschiceras baborense (Coquand) are relevant. The genus Partschiceras has been redefined and redescribed by Wiedmann (1963, pp. 229-51) while Schindewolf (1961, p. 76, fig. 36) investigated the ontogenetic development of the suture line of a $P$. aff. subobtusum (Kudernatsch).

\section{Species Partschiceras baborense (Coquand)}

(Fig. 5a-d, 6b, 7d-e)

1880 Ammonites Baborensis Coquand, p. 26.

1912 Phylloceras infundibilum var. Baborensis Coquand; Joleaud, p. 110, pl. 1, figs 1-3.

1937 Phylloceras baborense Coquand; Collignon, p. 8, pl. 1, figs 4-6.

1963 Partschiceras baborense (Coquand); Wiedmann, p. 243, pl. 14, figs 2, 4, 5; pl. 16, figs 1 , 2; fig. 59 (cum synon).

Material. The material available for comparison was collected by W. Bodmer (Museum of Natural History in Basel) from the Upper Aptian of Mallorca in the vicinity of San Telmo, on the western end of the island, at Punta Negra.

Discussion. Besides other cephalopods indicating a late Aptian age, Bodmer's collection contains numerous specimens of well-preserved Partschiceras baborense. Their preservation is comparable to those described by Wiedmann (1963) from the Upper Aptian of the Province of Alicante and Cala Blanca on Mallorca. The ammonites consist predominantly of limonite, but some chambers are filled with calcite crystals. The thin test has generally been eroded or dissolved from most of the specimens. One specimen, however, has some fragments of the test preserved (Fig. 5a,b). Here, a fine, dense ribbing, as known in Phylloceras (Hypophylloceras), can be clearly seen. These fine ribs begin on the dorsal third of the flank and cross over the venter. In order to verify this 

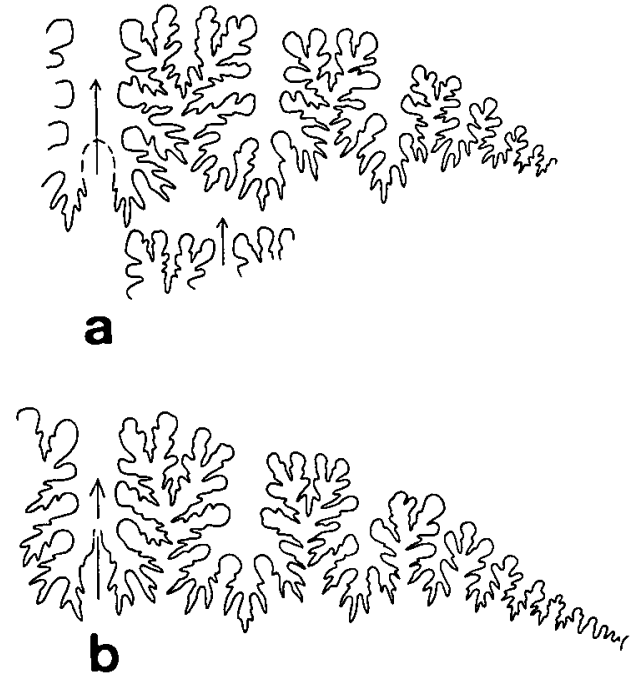

\section{$2 \mathrm{~mm}$}

Figure 6. (a) External suture line of Partschiceras whiteavesi (Kossmat), Utatur Group, Odium, southern India (at diameters 15 (above) and $10 \mathrm{~mm}$ (below)). Museum of Natural History, Geneva, Wi 'UAM'/3. (b) External suture line of Partschiceras baborense from San Telmo, Mallorca (at diameter $15 \mathrm{~mm}$ ). Museum of Natural History, Basel, no J 31316 .

observation, part of the outer whorl was removed from some specimens. The ribbing is well preserved on the venter of the adjoining inner whorl, where parts of the test remained attached (Fig. $5 \mathrm{~b}, \mathrm{c}$ ). This confirms an observation made already by Collignon $(1937$, p. 9$)$ on material of $P$. baborense from the Aptian of Madagascar: 'Aucune ornementation, sauf sur quelques rares échantillons encore munis du test, de très fines costules ordonnées en faisceaux à partir de la fosse ombilicale est parfois visible à la loupe.' This ribbing on $P$. baborense had not been considered by previous workers, and its assumed absence led to the view that a relationship between supposedly smooth Partschiceras of the Aptian and ribbed forms from the Cenomanian was doubtful (Wiedmann, 1963, p. 259).

The present observation confirms the relationship between P. baborense from the Upper Aptian and the younger representatives of the genus Partschiceras occurring in the Cenomanian. This mainly concerns Partschiceras whiteavesi (Kossmat) from the Utatur Group of Odium (southern India) of Cenomanian age (as figured by Wiedmann, 1963, p. 249). Figure 58 of Wiedmann (1963) shows the fine ribbing present on the test of this species. $P$. whiteavesi cannot be distinguished by adult morphological features from $P$. baborense: it has an equally broad-oval to subcircular whorl section, fine ribbing on the test, and even the suture line, when fully developed in the adult stage, appears very much alike in the two species (Fig. 6a, b; compare Fig. 6 a also with Wiedmann, 1963, p. 251, fig. 59).

An important difference, separating $P$. baborense from $P$. whiteavesi has been found in the ontogenetic development of the suture line of the juvenile stages: the innermost suture line exposed on a $P$. whiteaves $i$ from India (Fig. 6a below), at a diameter of $10 \mathrm{~mm}$ and a whorl height of $5.5 \mathrm{~mm}$, displays a much more pronounced tetraphyllic pattern than that found in $P$. baborense at an equal whorl height (Fig. $7 \mathrm{e}$; diameter $11 \mathrm{~mm}$, whorl height $6 \mathrm{~mm}$ ). This, according to our present knowledge, represents the only difference separating $P$. baborense (Upper Aptian) from $P$. whiteavesi (Cenomanian).

A description of the suture of the Partschiceras from Fuerteventura (which in our opinion should be compared with $P$. whiteavesi from southern India) is given below.

\section{Species Partschiceras cf. whiteavesi (Kossmat)}

(Fig. 6a, 7a-c)

1895 Phylloceras Forbesianum d'Orbigny; Kossmat, p. 109, pl. 15, fig. 1 a-c.

1898 Phylloceras whiteavesi Kossmat, pp. 124, 142.

1963 Partschiceras(?) whiteavesi (Kossmat); Wiedmann, p. 249, fig. 58.

Description and discussion. The measurements in Table I differ within narrow limits only. No traces of test are preserved, but the suture lines are remarkably well exposed. Conspicuous is the more advanced tetraphyllic pattern of the external saddle on the specimen from Fuerteventura than that of $P$. baborense from Mallorca at similar diameters. At a diameter of about $6 \mathrm{~mm}$, the external saddle of $P$. baborense is still clearly biphyllic and develops towards a tetraphyllic pattern only between diameters of 7.5 and $11 \mathrm{~mm}$ (Fig. $7 \mathrm{~d}, \mathrm{e}$ ). In contrast, $P$. cf. whiteavesi already displays a fully developed tetraphyllic pattern from a diameter of $5 \mathrm{~mm}$ onwards (Fig. $7 \mathrm{c}$ ). At that size, the suture compares well with that of a much larger $P$. baborense, as illustrated by Wiedmann (1963, p. 251, fig. 59a).

We conclude that at progressively younger stratigraphical levels the appearance of the tetraphyllic

Table 1. Measurements of Partschiceras specimens

\begin{tabular}{lclcrrrr}
\hline & Specimen no. & Age/location & Dm (mm) & Wh (mm) & Ww (mm) & Ww/Wh \\
\hline P. baborense & J 31318 & Aptian/Mallorca & 11.5 & $7(0.61)$ & $6.3(0.54)$ & 0.90 \\
$P$. whiteavesi & 'UAM'/3 & Cenomanian/India & 22 & $13.6(0.62)$ & $12.1(0.55)$ & 0.89 & \\
$P$. cf. whiteavesi & J 31317 & Fuerteventura & 8 & $4.5(0.56)$ & $4(0.50)$ & 0.89 & \\
\hline
\end{tabular}




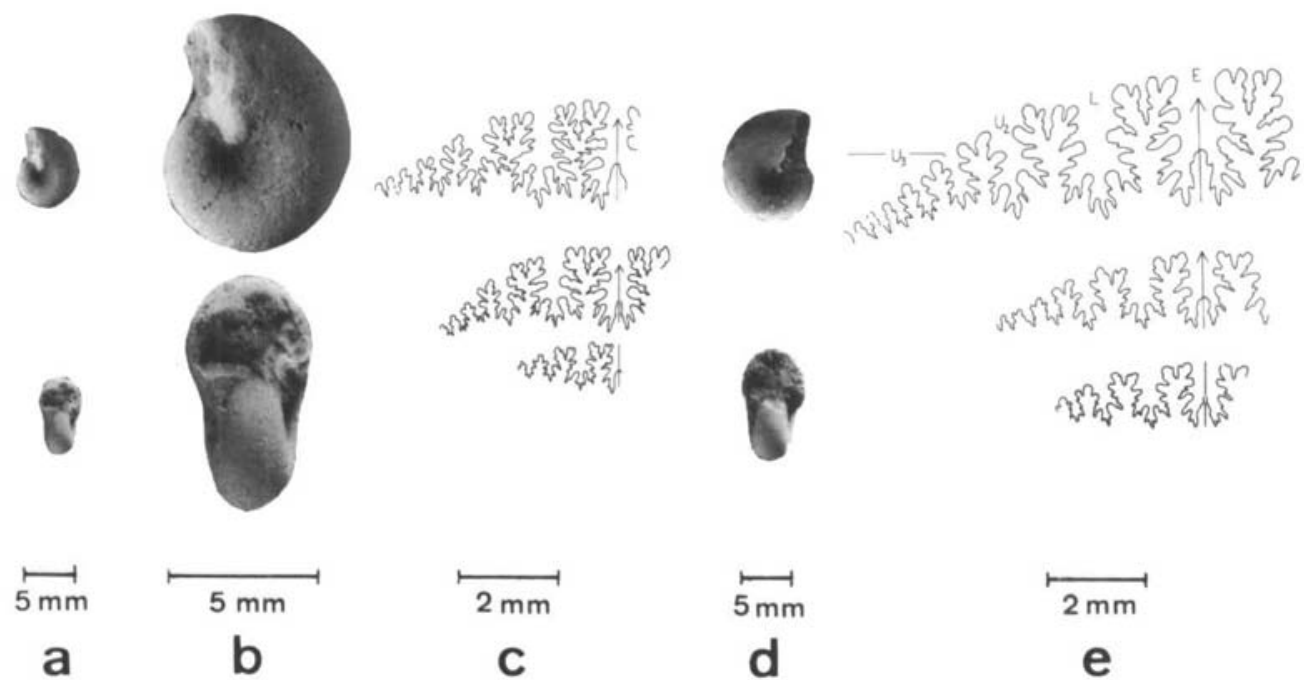

Figure 7. (a,b) Partschiceras ef. whiteavesi (Kossmat) from stratigraphical Unit F, Caleta de la Peña Vieja, Fuerteventura (Canary Islands). Museum of Natural History, Basel, no. J 31317. (c) Suture lines of $P$. cf. whiteavesi (specimen illustrated in a, b) at diameters of 3.6, 5.2 and $6 \mathrm{~mm}$. Museum of Natural History, Basel, no. J 31317. (d) Partschiceras baborense (Coquand) from the Upper Aptian of San Telmo, Mallorca. Museum of Natural History, Basel, no J 31318. (e) Suture lines of $P$. baborense (specimen illustrated in d) at diameters of $6,7.5$ and $11 \mathrm{~mm}$. Museum of Natural History, Basel, no. J 31318.

pattern occurs at successively earlier ontogenetic stages. Based on this observation, we propose a latest Albian to early Cenomanian age as most likely for the Partschiceras under discussion. This age is in line with the foraminiferal assemblage (Schackoina gandolfi Reichel, Rotalipora sp., Hedbergella sp., Gabonella sp.) co-occurring with the amonite.

\section{Conclusions}

Neocomites found in Unit D dates this turbidite sequence as Valanginian to Hauterivian, and shows it to be a deep-water equivalent of the Wealden-type 'Sables de Tantan' of the Aaiun (Tarfaya) Basin of the African mainland. In a larger context, these Lower Cretaceous turbidites reflect an interval of warm and humid climate, favouring the accumulation of siliciclastics during times of global sea-level highstands (Robertson \& Bliefnick, 1983; Weissert, 1990), and are well documented along the western AtlanticTethyan seaway (von Rad \& Sarti, 1986; Weissert, 1990). Interestingly Neocomites is also reported from comparable deposits of partly similar facies of the central Atlantic. An ammonite of the group of Neocomites neocomiensis (d'Orbigny) has also been described from deeper marine Hauterivian silt- and mudstones drilled at DSDP Site 397 on the continental slope south of Fuerteventura (Wiedmann, 1979), and a Neocomites sp., similar to our specimen, has been found in a silty deep-water limestone of the BlakeBahama Formation (Valanginian) at DSDP Site 534 of the Blake-Bahama Basin (Renz, 1983).

Partschiceras cf. whiteavesi from Unit $\mathrm{F}$ confirms the late Albian to early Cenomanian age established for these pelagic limestones by planktonic foraminifera (see above, Section 2). These limestones were deposited under high fertility and up-welling conditions, as shown by the abundance of radiolarians, fish teeth and phosphatized debris. An unstable slope environment of deposition is suggested by slumping and mass flow deposits (Robertson \& Bernoulli, 1982). These observations are in line with the overall evolution of the northwest African continental margin during the late Albian-Cenomanian interval which was characterized by gravitational instability (e.g. Lancelot $e t$ al. 1980).

Acknowledgements. We thank W. J. Kennedy and A. H. F. Robertson for critical review of the paper and W.J. Kennedy and C. W. Wright for much information regarding taxonomy. R. Panchaud helped during preparation of the manuscript. D. Decrouez and C. Meister kindly provided material for comparison.

\section{References}

Collignon, M. 1937. Paléontologie de Madagascar. XXII. Les ammonites pyriteuses de l'Aptien d'Antanatanamirafy. Annales de Paléontologie 26, 107-32, 3 pls.

CoQuAND, H. 1880. Etudes supplémentaires sur la paléontologie algérienne. Bulletin de l'Académie Hippone 15, $449 \mathrm{pp}$.

FUCINI, A. 1923. Fossili domeriani dei dintorni di Taormina. Parte prima. Palaeontografia Italica 26 (1920), 75-116.

Fuster, J. M., Cendrero, A., Gastesi, P., Ibarrola, E. \& LOPEZ RuIZ, J. 1968. Geologia y volcanología de los Islas Canarias - Fuerteventura. Madrid: Instituto Lucas Mallada, Consejo Superior de Investigaciones Científicas, $239 \mathrm{pp}$.

Grunau, H. R., Lehner, P., Cleintuar, M. R., Allen- 
BACH, P. \& Bakker, G. 1975. New radiometric ages and seismic data from Fuerteventura (Canary Islands), Maio (Cape Verde Islands) and São Tomé (Gulf of Guinea). In Progress in Geodynamics (eds G. J. Borradaile, A. R. Ritsema, H. E. Rondeel and O. J. Simon), pp. 89-108. Royal Netherlands Academy of Arts and Science. Amsterdam, New York: North Holland Publishing Co.

Joleaud, L. 1912. Etude géologique de la Chaîne Numidique et des Monts de Constantine (Algérie). Paris: Thèse, 436 pp., 8 pls.

Kossmat, F. 1895. Untersuchungen über die südindische Kreideformation (Erster Teil). Beiträge zur Paläontologie (Geologie) Oesterreich-Ungarns und des Orients 9, 97-203, pls 15-25.

Kossmat, F. 1898. Untersuchungen über die südindische Kreideformation (Dritter Teil). Beiträge zur Paläonrologie (Geologie) Oesterreich-Ungarns und des Orients 11, 89-152, pls 14-19.

lancelot, Y., Seibold, E., Dean, W. E., Jansa, L. F., Eremeev, V., Gardner, J., Cepek, P., Krasheninnikov, V. A., Pflaumann, U., Johnson, D., Rankin, J. G. \& Trabant, P. 1977. Initial Reports of the Deep Sea Drilling Project, vol. 41. Washington: United States Government Printing Office, $1259 \mathrm{pp}$.

Lancelot, Y., Winterer, E. L., Bosellini, A., Boutefeu, A. G., Boyce, R. E., Cepek, P., Duane, F., Galimov, E. M., Melguen, M., Price, I., Schlager, W., Sliter, W., TAGuChi, K., Vincent, E. \& WestberG, J. 1980. Initial Reports of the Deep Sea Drilling Project, vol. 50. Washington: United States Government Printing Office, $1079 \mathrm{pp}$.

Le Bas, M. J., Rex, C. D. \& Stillman, C. J. 1986. The early magmatic chronology of Fuerteventura, Canary Islands. Geological Magazine 123, 287-98.

Mitchell-Thomé, R. C. 1976. Geology of the Middle Atlantic Islands. Berlin: Gebrüder Bornträger, $382 \mathrm{pp}$

Renz, O. 1983. Early Cretaceous cephalopoda from the Blake Bahama Basin (Deep Sea Drilling Project Leg 76, Hole 534A) and their correlation in the Atlantic and Southwestern Tethys. In Initial Reports of the Deep Sea Drilling Project, vol. 76 (eds R. E. Sheridan et al.), pp. 693-744. Washington: United States Government Printing Office.

Robertson, A. H. F. \& Bernoulli, D. 1982. Stratigraphy, facies and significance of Late Mesozoic and Early Tertiary sedimentary rocks of Fuerteventura (Canary Islands) and Maio (Cape Verde Islands). In Geology of the Northwest African Continental Margin (eds. U. von Rad et al.), pp. 498-525. Berlin: Springer.

Robertson, A. H.F. \& Bliefnick, D. M. 1983. Sedimentology and origin of Lower Cretaceous pelagic carbonates and redeposited clastics, BlakeBahama Formation, Deep Sea Drilling Project Site 534, Western Equatorial Atlantic. In Initial Reports of the Deep Sea Drilling Project, vol. 76 (eds R. E.
Sheridan et al.), pp. 795-828. Washington: United States Government Printing Office.

Robertson, A. H. F. \& Stillman, C. J. 1979a. Late Mesozoic sedimentary rocks of Fuerteventura, Canary Islands: implications for West African continental margin evolution. Journal of the Geological Society, London 136, 47-60.

Robertson, A. H. F. \& Stillman, C. J. $1979 b$. Submarine volcanic and associated sedimentary rocks of the Fuerteventura Basal Complex, Canary Islands. Geological Magazine 116, 203-14.

RothE, P. 1968. Mesozoische Flysch-Ablagerungen auf der Kanareninsel Fuerteventura. Geologische Rundschau 58, 314-32.

SAlFeld, H. 1921. Kiel- und Furchenbildung auf der Schalenaussenseite der Ammonoideen in ihrer Bedeutung für die Systematik und Festlegung von Biozonen. Centralblatt für Mineralogie, Geologie und Paläontologie 1921, 343-7.

SAYN, G. 1901-1907. Les ammonites pyriteuses des marnes valangiennes du Sud-Est de la France. Mémoires de la Société Géologique de France 23, 66 pp., 6 pls.

ScHindewolf, O. H. 1961. Studien zur Stammesgeschichte der Ammoniten. Abhandlungen der Akademie der Wissenschaften und Literatur, mathematisch-naturwissenschaftliche Klasse 10, Lief. 1, 109 pp.

Stillman, C. J., Fuster, J. M., Bennell-Baker, M. J., Muñoz, M., Smewing, J. D. \& Sagredo, J. 1975. Basal complex of Fuerteventura (Canary Islands) is an oceanic intrusive complex with rift-system affinities. Nature 257, 469-71.

UhLIG, V. 1906. Einige Bemerkungen über die Ammonitengattung Hoplites Neumayr. Sitzungsberichte der kaiserlichen Akademie der Wissenschaften (Wien), mathematisch-naturwissenschaftliche Klasse 114/7 (1905), 591-636.

VON RAD, U. \& SARTI, M. 1986. Early Cretaceous 'events' in the evolution of the eastern and western North Atlantic continental margins. Geologische Rundschau 75, 139-58.

Weissert, H. 1990. Siliciclastics in the Early Cretaceous Tethys and North Atlantic Oceans: documents of periodic greenhouse climatic conditions. Memorie della Società Geologica Italiana 44, 59-69.

WIEDMANN, J. 1963. Unterkreide-Ammoniten von Mallorca. 2. Lieferung: Phylloceratina. Abhandlungen der Akademie der Wissenschaften und Literatur, mathematisch-naturwissenschaftliche Klasse 4, 151-264, pls $11-21$.

WIEDMANN, J. 1979. Early Cretaceous mollusks from DSDP Hole 397A off Northwest Africa. In Initial Reports of the Deep Sea Drilling Project, vol. 47(1) (eds U. von Rad et al.), pp. 283-7. Washington: United States Government Printing Office.

ZitTel, K. A. 1884. Handbuch der Palaeontologie, I. Abteilung, II. Band, 3. Klasse Cephalopoda. Kopffüsser, pp. 329-522. München and Leipzig: R. Oldenburg (1881-1885). 